therefore not surprising that the most effective treatment, judged by balance studies, appears to be the combination of $1 \alpha-$ hydroxycholecalciferol (or 1,25-dihydroxycholecalciferol) and oestrogens. ${ }^{1516}$

\section{References}

${ }^{1}$ Gallagher, J C, et al, Clinics in Endocrinology and Metabolism, 1973, 2, 293.

${ }^{2}$ Marshall, D H, et al, in Consensus on Menopause Research, ed P A van Keep, R B Greenblatt, and M Albeaux-Fernet, p 100. Lancaster, MTP Press, 1976

${ }^{3}$ Nordin, B E C, et al, Current Medical Research Opinion, 1975, 3, suppl No 3 , p 28.

${ }_{4}^{4}$ Nordin, B E C, et al, Frontiers of Hormone Research, 1975, 3, 131.

${ }^{5}$ Nordin, B E C, et al, Clinical Endocrinology, 1976, 5, suppl p 353s.

${ }^{6}$ Gallagher, J C, et al, Clinical Research, 1976, 24, 580A.
${ }^{7}$ Hemsell, D L, et al, fournal of Clinical Endocrinology and Metabolism, $1974,38,476$.

${ }_{8}$ Pelc, B, et al, Clinical Science and Molecular Medicine. In press.

9 Urist, M R, and Vincent, P J, Clinical Orthopaedics, 1960, 18, 199.

${ }^{10}$ Hollo, I, et al, Lancet, 1976, 1, 1357.

11 Judd, $\mathrm{H} \mathrm{L}$, et al, fournal of Clinical Endocrinology and Metabolism, 1974, 39, 1020.

12 Longcope, C, in The Menopausal Syndrome, ed R B Greenblatt, V B Mahesh, and P G McDonough, p 6. New York, Medicon Press, 1974.

${ }_{13}$ Albright, F, Smith, P H, and Richardson, A M, fournal of the American Medical Association, 1941, 116, 2465.

14 Riggs, B L, and Gallagher, J C, in Vitamin D Biochemical, Chemical and Clinical Aspects Related to Calcium Metabolism, ed A W Norman, et al, p 639. New York, 1977.

15 Marshall, D H, et al, in Calcified Tissues 1976, ed W G Robertson, B E C Nordin, and F G E Pautard, p 78. Berlin, Springer, 1977.

16 Marshall, D H, and Nordin, B E C, Clinical Endocrinology, In press.

\title{
Prolactin concentrations in ovulatory but infertile women: treatment with bromocriptine
}

\author{
ELIZABETH A LENTON, OLADELE S SOBOWALE, IAN D COOKE
}

British Medical fournal, 1977, 2, 1179-1181

\section{Summary}

We measured basal plasma prolactin concentrations (in samples obtained during the early follicular phase) in 25 normal (control) women and in a similar group of $\mathbf{4 0}$ patients with a long-standing history of infertility. The infertile patients were all ovulating regularly, and had been unsuccessfully treated with clomiphene and in some cases dydrogesterone and human menopausal gonadotrophin. Although none of the patients had plasma prolactin concentrations $>1000 \mu \mathrm{U} / \mathrm{ml}, 47 \cdot 5 \%$ of the estimations were greater than 1 standard deviation (SD) above the mean established for our control group. This difference was highly significant $(P<0.001)$. Treatment with various bromocriptine regimens effectively reduced prolactin concentrations to below normal in all cases, and 16 pregnancies followed-13 during bromocriptine treatment and three in the first post-treatment cycle. The cumulative conception rate was $63.4 \%$ after 10 months' treatment.

\section{Introduction}

Plasma prolactin concentrations are consistently raised in patients with Chiari-Frommel syndrome ${ }^{1}$ and in some amenorrhoeic women with or without galactorrhoea. ${ }^{2-6}$ Treatment with bromocriptine (2-bromo- - -ergocryptine) has effectively reduced circulating prolactin concentrations, and induced ovulation (and conception) in most. ${ }^{1-8}$ Bromocriptine may also restore cyclical menstruation in euprolactinaemic amenorrhoea, ${ }^{9}$ and improve luteal function in normally men-

\footnotetext{
University Department of Obstetrics, Jessop Hospital for Women, Sheffield S3 7RE

ELIZABETH A LENTON, PHD, research biochemist OLADELE S SOBOWALE, $M B$, BS, research assistant IAN D COOKE, FRCOG, professor of obstetrics and gynaecology
}

struating patients who nevertheless have hyperprolactinaemia and short luteal phases. ${ }^{1011} \mathrm{We}$ undertook the present study to determine whether an appreciable number of regularly ovulating women with long-standing infertility also have raised plasma prolactin concentrations, and to determine the therapeutic effectiveness of treatment with bromocriptine for this particular type of infertility.

\section{Patients and methods}

Initially 40 patients with long-standing infertility (range 2-10 years) were selected for assessment of basal prolactin concentrations and treatment with bromocriptine. Although $13(32.5 \%)$ of the women had had a previous pregnancy this had ended in an abortion in 10 $(25 \%)$ and a full-term intrauterine death in one patient. Only two patients had given birth to a living child. These women had all been fully investigated and were found to be ovulating regularly, with cycles of normal length (25-35 days). No reason for their infertility was shown by routine investigations (which included seminal analysis, hysterosalpingogram in all patients, and laparoscopy in 20), but we felt that these patients were similar to women with defective luteal phases. ${ }^{12}{ }^{13}$ Preliminary findings showed that none of these women had a short luteal phase-that is, a luteal phase lasting less than 10 days (criteria of Sherman and Korenman ${ }^{14}$ ) -and that they had ovulated in the cycles investigated. We considered ovulation to have occurred if a surge of luteinising hormone preceded a rise of plasma progesterone in all cases. Blood samples for prolactin measurement were obtained on two occasions (between 0800 and 1000 hours) within the first five days of each patient's basal cycle. Similar samples were obtained at the same time in the cycle from a group of 25 normal (control) women - that is, fertile women with no known gynaecological or medical abnormality or relevant drug history. Plasma was separated within 45 minutes and stored at $-20^{\circ} \mathrm{C}$ until assayed for prolactin.

Hormone assay-Plasma prolactin was measured by radioimmunoassay, ${ }^{15}$ using the reagents provided by the National Pituitary Agency (antiserum and hormone for labelling), and the standard distributed by the Medical Research Council Division of Biological Standards (Research Standard A71/222), which was used to calibrate our own laboratory standard (a pool of serum from lactating women). All results are expressed in $\mu \mathrm{U} / \mathrm{ml}$ in terms of the MRC $71 / 222$ preparation. (Approximately $40 \mu \mathrm{U} / \mathrm{ml}$ of this are equivalent to $1 \mathrm{ng} / \mathrm{ml}$ $\mathrm{NIH}$ VLS1). All the prolactin estimations were performed in two assays to eliminate possible interassay variation.

Treatment regimen-The patients were randomly allocated to one of four groups. Bromocriptine (Parlodel, Sandoz) was given throughout 
the cycle in one of the following dose regimens: $2.5 \mathrm{mg}$ twice daily; $1.25 \mathrm{mg}$ thrice daily; $1.25 \mathrm{mg}$ twice daily; and $1.25 \mathrm{mg}$ twice daily with $50 \mathrm{mg}$ clomiphene citrate (Clomid, Merrell) on days 2 to 6 of the cycle. A few patients were eventually included in more than one treatment group. The effect of treatment on the plasma prolactin concentrations was monitored for the first two treatment cycles by assaying a single plasma sample obtained as above within the first five days of each cycle. Blood was not collected for prolactin estimation until 48 hours after the start of treatment, to allow the prolactin concentrations to stabilise. ${ }^{2}$

\section{Results}

The distribution of basal prolactin concentrations in the normal women and the infertile patients are shown in fig 1 . Although the ranges of plasma prolactin were not greatly different, the distribution for the infertile women was clearly shifted to the right. Furthermore, neither of these distributions was "normal," and probit analysis showed them to conform much more closely to log-normal distributions. For this reason we used log-means $( \pm S D)$ to define our normal range and for statistical comparisons with the infertile group (table I). The difference between the mean concentrations was highly significant $(P<0 \cdot 001$, Student's $t$ test). Similarly, when the number of prolactin estimations greater than 1 SD above the normal mean $(.300: \mathrm{L} / \mathrm{ml})$ were compared for the two groups, the differences $(18.4 \%$ of the normal values and $47.5 \%$ of the infertile patients' results) were again significant $\left(\mathrm{P}<0.001, \chi^{2}\right.$ test $)$.

Treatment with bromocriptine reduced prolactin concentrations to below the normal range in most cases (normal mean -2 SD is 106 $: \mathrm{U} / \mathrm{ml}$ ), and sometimes to below the lower limit of sensitivity of the assay $(50 \mu \mathrm{U} / \mathrm{ml})$. The results of treatment with the different regimens are shown in table II, and again log-mean values have been used.

TABLE I-Plasma prolactin concentrations $(\mu U \mathrm{ml})$ in normal women and in ovulatory but infertile women. Figures in parenthese's are numbers of estimations

\begin{tabular}{|c|c|c|c|c|}
\hline Group & Log-mean SD & Mean & Mean + SD & Mean-SD \\
\hline $\begin{array}{l}\text { Normal } \\
\text { Infertile }\end{array}$ & $\begin{array}{l}\begin{array}{l}* 5.38: 0.36(50) \\
* 5.69\end{array} 0.45(80)\end{array}$ & $\begin{array}{l}217 \\
297\end{array}$ & $\begin{array}{l}311 \\
464\end{array}$ & $\begin{array}{l}151 \\
189\end{array}$ \\
\hline
\end{tabular}

*P $<0.001$ (Student's $t$ test).

TABLE II-Prolactin concentrations before and after treatment with four different bromocriptine regimens. Numbers of estimations and ranges given in first and second set of parentheses respectively

\begin{tabular}{|c|c|c|c|}
\hline \multirow{2}{*}{ Regimen } & \multicolumn{3}{|c|}{ Mean plasma prolactin $(\mu \mathrm{U} \mathrm{ml})$} \\
\hline & Pretreatment* & $\begin{array}{l}\text { 1st treatment } \\
\text { cycle }\end{array}$ & $\begin{array}{l}\text { 2nd treatment } \\
\text { cycle }\end{array}$ \\
\hline $\begin{array}{l}2.5 \mathrm{mg} \text { twice daily } \\
1.25 \mathrm{mg} \text { thrice daily } \\
1.25 \mathrm{mg} \text { twice daily } \\
1.25 \mathrm{mg} \text { twice daily + clomiphene }\end{array}$ & $\begin{array}{l}275 \cdot 0(14) \\
(185-412) \dagger \\
290.0(12) \\
(219-384) \\
296.0(11) \\
(204-428) \\
399 \cdot 0(7) \\
(290-550)\end{array}$ & $\begin{array}{l}61 \cdot 0(14) \\
(38-98) \\
75 \cdot 0(12) \\
(47-119) \\
72 \cdot 0(11) \\
(47-111) \\
74 \cdot 0(7) \\
(37-145)\end{array}$ & $\begin{array}{l}70 \cdot 0(9) \\
(40-126) \\
77 \cdot 0(9) \\
(47-128) \\
110 \cdot 0(9) \\
(65-187)\end{array}$ \\
\hline
\end{tabular}

*The average value of the two pretreatment samples was used in the calculation of the mean. the mean.
$+67^{\circ}$ " confidence limits.

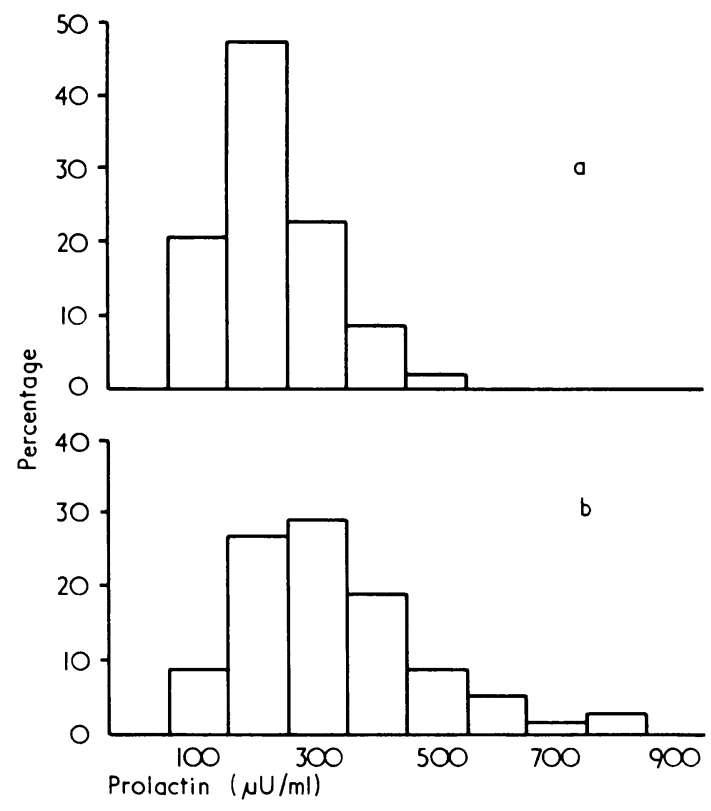

Distribution of basal plasma prolactin concentrations in 25 normal (control) women (a) and in 40 infertile but ovulatory patients. (Number of estimations was 50 and 80 for controls and patients respectively.)

Sixteen of the infertile patients conceived, five within the first two treatment cycles, eight during subsequent treatment cycles, and three during the first cycle after withdrawal of treatment. Unfortunately, two of the pregnancies in the bromocriptine plus clomiphene group were ectopic (tubal). Nine of the remaining pregnancies resulted in the term delivery of a normal infant and four were continuing. The cumulative conception rate ${ }^{16}$ at the end of 10 treatment cycles was $63.4 \%$ (table III). If the three pregnancies which occurred in the first post-treatment cycle were omitted, the cumulative conception rate after 10 cycles became $55.1 \%$. Mean basal prolactin concentration was $275 ; \mathrm{U} / \mathrm{ml}$ in the patients who conceived and $311: \alpha \mathrm{U} / \mathrm{ml}$ in the patients who did not become pregnant. This difference was not significant.

\section{Discussion}

We initially decided to measure the prolactin concentration in only two samples from the first five days of the cycle so that we could measure all the samples in two assays. The day-to-day variation in plasma prolactin concentrations seems to be least at this stage of the cycle. ${ }^{17}$ Our normal mean and range of prolactin concentrations is slightly lower than those quoted by other authors, ${ }^{218}$ probably because we only included samples obtained in the early follicular phase, and plasma prolactin levels tend to rise $^{19}$ as the cycle progresses.

None of the infertile women had prolactin concentrations greater than $1000 \mu \mathrm{U} / \mathrm{ml}$, and therefore could not be considered to have gross hyperprolactinaemia. Nevertheless, the distribution of prolactin concentrations was significantly higher than in our

TABLE III-Cumulative conception rate in 40 ovulatory but infertile women after bromocriptine treatment

\begin{tabular}{|c|c|c|c|c|c|c|c|}
\hline $\begin{array}{l}\text { Treatment } \\
\text { cycle }\end{array}$ & $\begin{array}{l}\text { Not pregnant } \\
\text { at beginning } \\
\text { of cycle }\end{array}$ & $\begin{array}{c}\text { Pregnant } \\
\text { during cycle }\end{array}$ & $\begin{array}{l}\text { Stopped treatment } \\
\text { at end of cycle }\end{array}$ & $\begin{array}{c}\text { Proportion } \\
\text { pregnant }\end{array}$ & $\begin{array}{l}\text { Proportion } \\
\text { not pregnant }\end{array}$ & $\begin{array}{c}\text { Cumulative } \\
\text { proportion } \\
\text { not pregnant }\end{array}$ & $\begin{array}{c}\text { Cumulative } \\
\text { proportion } \\
\text { pregnant }\end{array}$ \\
\hline $\begin{array}{r}1 \\
2 \\
3 \\
4 \\
5 \\
6 \\
7 \\
8 \\
9 \\
10\end{array}$ & $\begin{array}{r}40 \\
32 \\
29 \\
24 \\
20 \\
17 \\
11 \\
9 \\
7 \\
4\end{array}$ & $\begin{array}{l}5 \\
1 \\
4^{*} \\
1 \\
1 \\
1^{*} \\
1 \\
1^{*}\end{array}$ & $\begin{array}{l}3 \\
2 \\
1 \\
3 \\
2 \\
5 \\
1 \\
2 \\
2 \\
2 \\
3\end{array}$ & $\begin{array}{l}0.125 \\
0.031 \\
0.138 \\
0.042 \\
0.050 \\
0.059 \\
0.091 \\
\\
0.143 \\
0.250\end{array}$ & $\begin{array}{l}0.875 \\
0.969 \\
0.862 \\
0.958 \\
0.950 \\
0.941 \\
0.909 \\
\\
0.857 \\
0.750\end{array}$ & $\begin{array}{l}0.875 \\
0.848 \\
0.731 \\
0.700 \\
0.665 \\
0.626 \\
0.569 \\
\\
0.488 \\
0.366\end{array}$ & $\begin{array}{l}0.125 \\
0.152 \\
0.269 \\
0.300 \\
0.335 \\
0.374 \\
0.431 \\
\\
0.512 \\
0.634\end{array}$ \\
\hline
\end{tabular}

*Conception in the first post-treatment cycle. 
normal group, although treatment with bromocriptine effectively suppressed circulating prolactin concentrations to below normal at all the dose levels studied.

Life-tables ${ }^{16}$ were used to calculate the cumulative conception rate because this method includes patients who cease treatment before the end of a study, and thus permits valid comparisons to be made between different studies. The cumulative conception rate reported here after bromocriptine treatment is dramatically different from the spontaneous conception rate obtained in a similar group of patients who were given no treatment. ${ }^{20}$ In the latter series only $43^{\prime \prime}$ " of the patients conceived spontaneously in a period of eight years (10" " in the first year of follow-up, whereas $63^{\circ}$ " of the patients in this study conceived in 10 months). The conception rate after bromocriptine in these infertile women is still less than the reported rates for a normal population. ${ }^{21}: 2:$

At this stage it is premature to speculate about the direct or indirect effects of bromocriptine on follicular maturation and function of the corpus luteum. The role of prolactin in the regulation of reproduction in these women is undoubtedly complex, ${ }^{23}$ and may well be only loosely related to circulating prolactin concentrations. ${ }^{* 4}$ Some mechanism apart from a mere reduction in plasma concentrations is needed to explain the resumption of menses in some euprolactinaemic women ${ }^{9}$ and not others." In our own series of ovulating women, the pregnancies that occurred were not among the patients with the highest prolactin concentrations, but were evenly distributed throughout the range of prolactin concentrations measured. Nonetheless, it seems most unlikely that the number of pregnancies obtained here in a group of women who normally are very difficult to treat successfully could be fortuitous and unrelated to bromocriptine administration. This new and apparently successful use of bromocriptine ${ }^{25}$ needs much careful research to establish not only the precise mode of action but also the type of ovulatory but infertile woman who is most likely to benefit from it.

We thank Miss $\mathrm{L}$ Brook for performing the luteinising hormone assays; Miss B McNeill for typing the manuscript; Sandoz Limited for financial support for one of us (EAL); and Mr A Singer for his co-operation in referring some of the patients.
Requests for reprints should be addressed to Dr E A Lenton, University Department of Obstetrics and Gynaecology, Jessop Hospital for Women, Sheffield S3 7RE.

\section{References}

1 Seki, K, and Seki, M, fournal of Clinical Endocrinology and Metabolism, $1974,38,508$

2 Pepperell, R J, et al, British fournal of Obstetrics and Gynaecology, 1977, 84, 58

Seppala, M, et al, British Medical fournal, 1975, 2, 305.

' del Pozo, E, et al, in Ovulation in the Human, ed P G Crosignani and D R Mishell, p 297. London, Academic Press, 1976.

5 Tyson, J E, et al, American Fournal of Obstetrics and Gynecology, 1975, $121,375$.

'Besser, G M, et al, British Medical fournal, 1972, 3, 669.

; Thorner, M O, et al, British Medical fournal, 1974, 2, 419.

8 Thorner, M O, et al, British Medical fournal, 1975, 4, 694.

9 Tolis, G, and Naftolin, F, American fournal of Obstetrics and Gynecology, 1976, 126, 426.

10 del Pozo, E, Varga, L, and Obolensky, W. Communication to Symposium on Ovulation in the Human. Freiburg, Germany, 10-12 September 1975.

${ }^{11}$ Corenblum, B, Pairandeau, N, and Shewchuk, A B, Obstetrics and Gynecology, 1976, 47, 486

12 Cooke, I D, et al, Fournal of Reproduction and Fertility, 1977, 51, 203.

${ }^{13}$ Lenton, E A, Adams, M, and Cooke, I D. In preparation.

${ }^{14}$ Sherman, B M, and Korenman, S G, fournal of Clinical Endocrinology and Metabolism, 1974, 38, 89.

${ }^{5}$ Reuter, A M, et al, International fournal of Nuclear Medical Biology, $1976,3,21$.

${ }_{16}$ Lamb, E J, and Cruz, A L, Fertility and Sterility, 1972, 23, 310.

17 Ehara, Y, et al, American fournal of Obstetrics and Gynecology, 1973, 117, 962 .

${ }^{18}$ Franchimont, P, et al, Radioimmunoassay of prolactin in health and disease, p 7. Brussels, Imprimerie Bietlot Frères, 1976.

${ }^{19}$ Robyn, C, et al, in Human Prolactin, ed J P Pasteels and C Robyn, p 167. New York, Excerpta Medica, American Elsevier, 1973.

${ }^{20}$ Lenton, E A, Weston, G A, and Cooke, I D, Fertility and Sterility, 1977. In press.

${ }^{21}$ Diddle, A W, Jack, R W, and Pearse, R L, American fournal of Obstetrics and Gynecology, 1947, 54, 57.

22 Tietze, C, Fertility and Sterility, 1956, 7, 88.

${ }^{23}$ Glass, M R, et al, British Medical fournal, 1975, 3, 274

${ }^{24}$ McNatty, K P, Sawers, R S, and McNeilly, A S, Nature, 1974, 240, 653.

${ }^{55}$ British Medical fournal, 1977, 1, 863.

(Accepted 1 September 1977)

\title{
Effects of sputum on pulmonary function
}

\author{
G M COCHRANE, B A WEBBER, S W CLARKE
}

British Medical fournal, 1977, 2, 1181-1183

\section{Summary}

The specific airways conductance (SGAW) of 23 patients with copious sputum production and airflow obstruction was measured before and after physiotherapy to deter-

\footnotetext{
Department of Thoracic Medicine, New Cross Hospital, London SE14 SER

G M COCHRANE, MB, MRCP, consultant physician

\section{Brompton Hospital, London}

B A WEBBER, MCSP, assistant superintendent, department of physiotherapy

S W CLARKE, MD, FRCP, consultant physician
}

mine the effect of bronchial secretions on pulmonary function. Chest physiotherapy to remove these secretions had the effect of reducing airflow obstruction, as measured by SGAW.

These findings suggest that sputum has a detrimental effect on pulmonary function and that physiotherapy can reduce airways obstruction.

\section{Introduction}

Although cough and sputum are the cardinal features of chronic bronchitis ${ }^{1}$ and are also associated with bronchiectasis and cystic fibrosis, few studies have been undertaken to assess the effect on pulmonary function of liquid secretions within the bronchial tree. Moreover, previous studies have not given conclusive 